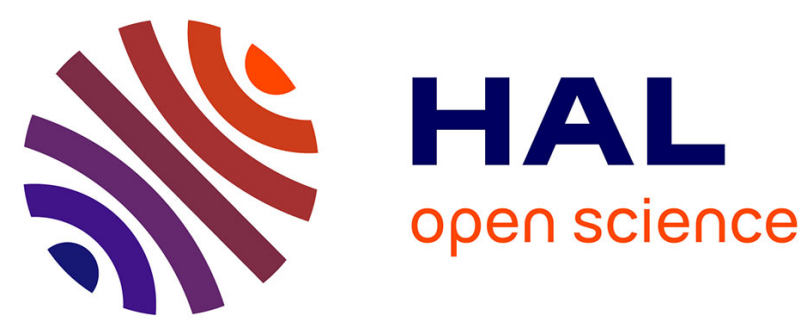

\title{
Modelling the continental effect of oxygen isotopes over Eurasia
}

\author{
Matthias Cuntz, Philippe Ciais, Gilles Hoffmann
}

\section{To cite this version:}

Matthias Cuntz, Philippe Ciais, Gilles Hoffmann. Modelling the continental effect of oxygen isotopes over Eurasia. Tellus B - Chemical and Physical Meteorology, 2002, 54 (5), pp.895-909. 10.3402/tellusb.v54i5.16738. hal-02676417

\section{HAL Id: hal-02676417 https://hal.inrae.fr/hal-02676417}

Submitted on 31 May 2020

HAL is a multi-disciplinary open access archive for the deposit and dissemination of scientific research documents, whether they are published or not. The documents may come from teaching and research institutions in France or abroad, or from public or private research centers.
L'archive ouverte pluridisciplinaire HAL, est destinée au dépôt et à la diffusion de documents scientifiques de niveau recherche, publiés ou non, émanant des établissements d'enseignement et de recherche français ou étrangers, des laboratoires publics ou privés.

\section{다)(1) $(5$}

Distributed under a Creative Commons Attribution - NonCommercial| 4.0 International 


\title{
Modelling the continental effect of oxygen isotopes over Eurasia
}

\author{
By MATTHIAS CUNTZ ${ }^{1,2 *}$, PHILIPPE CIAIS ${ }^{1}$ and GEORG HOFFMANN ${ }^{1},{ }^{1}$ Laboratoire des Sciences \\ du Climat et de l'Environnement (LSCE), UMR CEA-CNRS 1572, 91191 Gif-sur-Yvette Cedex, France; \\ ${ }^{2}$ Institut für Umweltphysik (UHEI-IUP), Universität Heidelberg, Im Neuenheimer Feld 229, 69120 \\ Heidelberg, Germany
}

(Manuscript received 9 July 2001; in final form 22 April 2002)

\begin{abstract}
$\delta^{18} \mathrm{O}$ in $\mathrm{CO}_{2}$ attracts attention for its ability to decipher the gross fluxes of terrestrial $\mathrm{CO}_{2}$ exchange. This capacity can only be exploited if one knows the impact of the biology and the water isotope cycle on the isotopic composition of atmospheric $\mathrm{CO}_{2}$. To study the processes, we built an integrated global model of $\delta^{18} \mathrm{O}$ in atmospheric $\mathrm{CO}_{2}$ that calculates ${ }^{18} \mathrm{O}$ in the water cycle pools, the $\mathrm{CO}_{2}$ and the inherent $\delta^{18} \mathrm{O}-\mathrm{CO}_{2}$ fluxes and transports these in the atmosphere. Within the framework of the European Project EUROSIBERIANCARBONFLUX, we investigated the ${ }^{18} \mathrm{O}$ processes on the continent of Eurasia north of $40^{\circ} \mathrm{N}$. We show that there is a large impoverishment in the water isotopic composition of rain in the continental interior but this is significantly reduced during the growing season. We validated the model directly by comparing it to Net Ecosystem Exchange (NEE) measurements from eddy-flux towers and indirectly by comparing it to atmospheric measurements of $\mathrm{CO}_{2}$ and $\delta^{18} \mathrm{O}_{-} \mathrm{CO}_{2}$ at $3000 \mathrm{~m}$ a.s.l. The model reproduces well the seasonal cycle of $\mathrm{CO}_{2}$ and the phase for $\delta^{18} \mathrm{O}-\mathrm{CO}_{2}$ but it underestimates the amplitude of that species. Our model further predicts a large diurnal rectifier effect that is different in $\mathrm{CO}_{2}$ than in $\delta^{18} \mathrm{O}-\mathrm{CO}_{2}$ in eastern Siberia due to very low or even negative leaf discrimination. We analyse the longitudinal gradient in leaf discrimination which reflects primarily the gradient in leaf water isotopic composition. The leaf water $\delta^{18} \mathrm{O}-\mathrm{H}_{2} \mathrm{O}$ gradient is itself determined $25 \%$ by the meridional gradient in source water and $75 \%$ by the change of relative humidity with longitude.
\end{abstract}

\section{Introduction}

Our current knowledge does not yet allow to balance the global budget of carbon dioxide within better than $\pm 30 \%$ (Prentice et al., 2001). The present consensus is that there is a terrestrial carbon sink in the northern hemisphere. However, the contribution of different geographic locations as well as biomes is not yet clear. For example, it is a matter of debate how this sink is distributed between North America and Eurasia, and more so whether the North American continent and Eurasia are sources or sinks for $\mathrm{CO}_{2}$. Using inversion

\footnotetext{
${ }^{*}$ Corresponding author. e-mail: cuntz@1sce.saclay.cea.fr
}

techniques with current models does not provide an unequivocal distribution of $\mathrm{CO}_{2}$ sources and sinks (e.g. Bousquet et al., 2000; Rayner et al., 1999; Fan et al., 1998; Ciais et al., 1995). Given the existing distribution of $\mathrm{CO}_{2}$ stations, this problem is mathematically underconstrained and therefore needs further and independent constraints.

Though we aim to quantify the biospheric $\mathrm{CO}_{2}$ fluxes better. In the last few years, $\delta^{18} \mathrm{O}$ in atmospheric $\mathrm{CO}_{2}$ attracted attention to tackle this problem. Observations of the oxygen isotopic composition of $\mathrm{CO}_{2}$ have the capability to distinguish between gross carbon fluxes of the terrestrial biosphere, namely assimilation and respiration. Because of the isotopic exchange of $\mathrm{CO}_{2}$ with water (Mills and Urey, 1940), $\mathrm{CO}_{2}$ exchanged by the biospheric fluxes carries the isotopic 
signature of different water pools. These pools are the leaf water and the soil moisture, respectively. $\delta^{18} \mathrm{O}$ of atmospheric $\mathrm{CO}_{2}$ is therefore primarily a convolution of $\mathrm{CO}_{2}$ gross fluxes and water isotope signatures. In constraining the isotopic signature of the water pools interacting with carbon dioxide, we can estimate separately the gross $\mathrm{CO}_{2}$ biosphere fluxes.

The global ${ }^{18} \mathrm{O}$ signature of $\mathrm{H}_{2} \mathrm{O}$ in the unsaturated soil layer is about $-10 \%$ on average (vs. VSMOW, see below). However, the geographical distribution of the water isotopes is mainly controlled by the rainout of air masses transported to the interior of the continents. This mechanism produces extremely strong continental gradients of the isotopic composition of precipitation and of the corresponding soil water, and makes a detailed modelling of the abovementioned rain-out mechanism necessary. Subsequently when water evaporates, lighter molecules are preferentially evaporated leaving a heavier water pool. For example, water at the evaporating site of leaves is enriched by about 10$20 \%$ (vs. soil water). Net assimilation [which is the Gross Primary Productivity (GPP) minus leaf respiration and equals about 0.85 GPP] and net ecosystem respiration fluxes are around $100 \mathrm{GtC} \mathrm{yr}^{-1}$ (Schimel et al., 1996) whereas net exchange between biosphere and atmosphere (NBP) is only 0-2 GtC $\mathrm{yr}^{-1}$ globally. This means that the resulting $\delta^{18} \mathrm{O}-\mathrm{CO}_{2}$ signal is the result of (mainly) two huge opposing fluxes that we name hereafter "isofluxes", even more pronounced than for $\mathrm{CO}_{2}$ (Ciais et al., 1997a,b; Farquhar et al., 1993). From the convolution, it originates that a small change in the $\mathrm{CO}_{2}$ gross fluxes leads to a big change in the isofluxes. The biospheric gross fluxes should therefore be deducible (Peylin, 1999). Eurasia is the largest land mass in the northern hemisphere. Its role in the global carbon cycle is important but is not known precisely. In addition to $\mathrm{CO}_{2}$ fluxes, there is a special depletion in rainfall, and subsequent water pools in the biosphere in the interior of Eurasia (Dansgaard, 1964) which could lead to peculiar effects in $\delta^{18} \mathrm{O}$. Namely, one might expect leaf water $\delta^{18} \mathrm{O}-\mathrm{H}_{2} \mathrm{O}$ to be more negative than the atmosphere over most of the continental land mass, yielding photosynthesis to diminish $\delta^{18} \mathrm{O}$ in atmospheric $\mathrm{CO}_{2}$ rather than increasing it as usually expected. We have built a consistent global model of $\delta^{18} \mathrm{O}$ in atmospheric $\mathrm{CO}_{2}$ which calculates at each timestep the water isotopic composition of the different water pools (in leaves, in soils, and in the atmosphere), the $\mathrm{CO}_{2}$ and $\mathrm{CO}^{18} \mathrm{O}$ fluxes from and into the atmosphere, and finally the atmospheric $\mathrm{CO}_{2}$ concentration together with its $\delta^{18} \mathrm{O}$ -
$\mathrm{CO}_{2}$ value, including transport. Hence, we built a tool to investigate the $\mathrm{CO}_{2}$ cycle together with the $\delta^{18} \mathrm{O}$ cycles in $\mathrm{CO}_{2}$ and water because the exchange of $\mathrm{CO}_{2}$ and water is fully coupled in the model. Here we investigate the distribution of $\mathrm{CO}_{2}$ with $\delta^{18} \mathrm{O}$ over the interior of Eurasia. We compare our model results with literature data and measurements made within the European Project EUROSIBERIAN CARBONFLUX.

\section{Experimental and model set-up}

\subsection{The model}

The model combines the Atmospheric General Circulation Model (AGCM) ECHAM, including transport of inert tracers and the water isotope cycle, the biosphere model BETHY, and a newly built ${ }^{18} \mathrm{O}-\mathrm{CO}_{2}$ flux module (Fig. 1). ECHAM is the general circulation model of the Max-Planck Institut für Meteorologie (MPI-MET) in Hamburg, a state-of-the-art global climate model used in several studies (e.g. Arpe et al., 1994; Roeckner et al., 1992) [for a full model description see Modellbetreuungsgruppe (1994)]. In this study, we use the spectral model ECHAM in the T21 resolution corresponding to a physical grid of $5.6^{\circ} \times 5.6^{\circ}$ (40 min time step). The model has 19 vertical layers from surface pressure up to a pressure level of $30 \mathrm{hPa}$. It includes an inert tracer transport scheme which transports the tracer identical to the water vapour with the semi-Lagrangian advection scheme according to Rasch and Williamson (1990).

The water isotope module (WFRAC) was implemented in cycle 3 of ECHAM by Hoffmann et al. (1998) and later built into cycle 4 by Werner (2000). Herein, the water isotopes are treated exactly in parallel to the model's moisture. However, at each phase transition a temperature-dependent fractionation (Majoube, 1971) is applied to the water isotopes, continuously depleting the vapour phase compared to the liquid or solid phase.

We interfaced the process-based model of terrestrial vegetation activity, BETHY, to the AGCM ECHAM. It calculates at each time step of the AGCM, $\mathrm{CO}_{2}$ fluxes of the terrestrial biosphere together with further diagnostic variables such as stomatal conductance and vegetation temperature. The BETHY online model uses a conservative vegetation distribution map (Wilson and Henderson-Sellers, 1985) adjusted to 


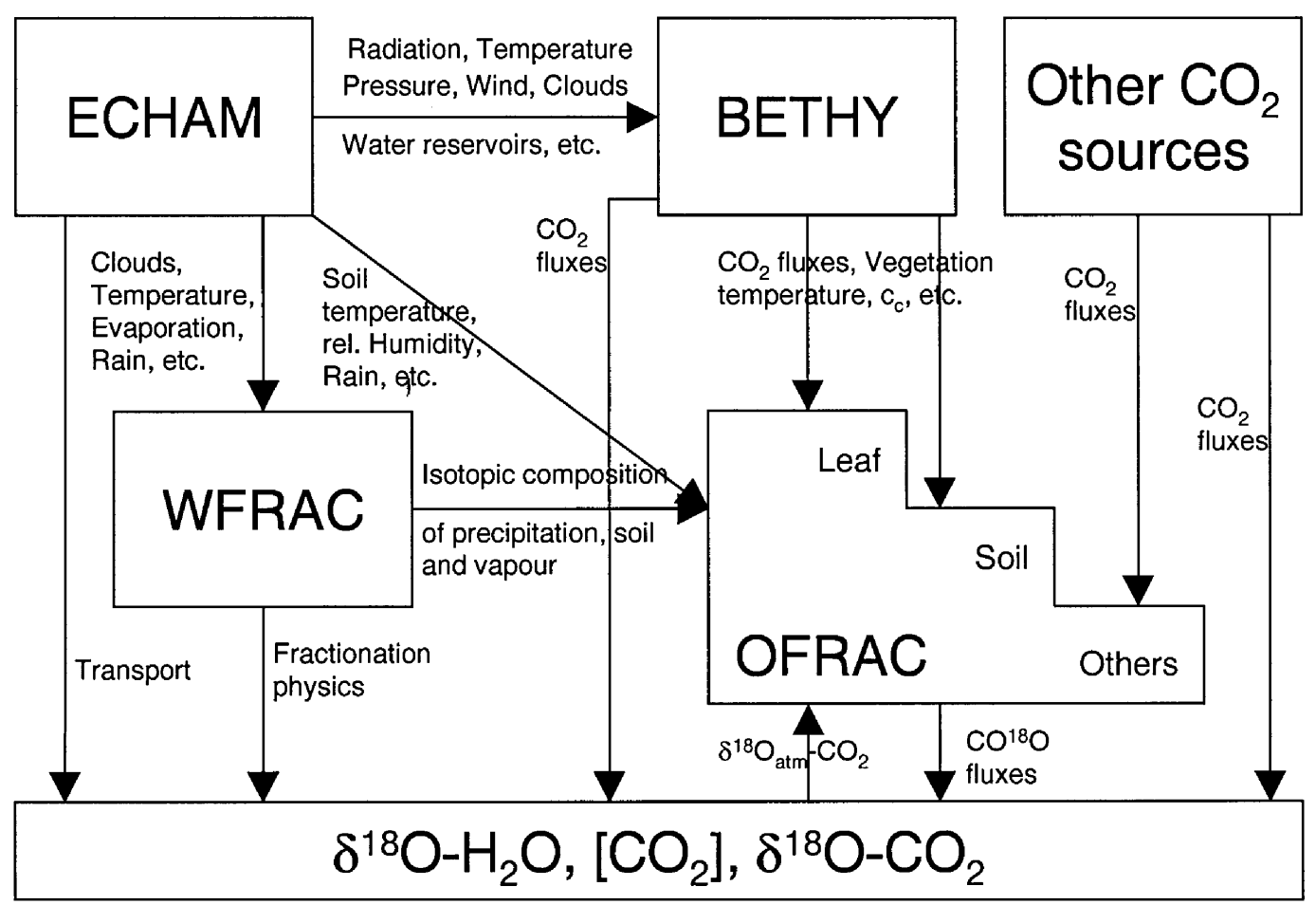

Fig. 1. Information flow of the coupled model. ECHAM is the atmospheric general circulation model (Modellbetreuungsgruppe, 1994); BETHY is the biosphere model (Knorr and Heimann, 2001a,b); other $\mathrm{CO}_{2}$ sources are monthly input fields, for example ocean fluxes; WFRAC is the water isotope module (Werner, 2000); OFRAC is the newly build $\mathrm{CO}_{2}$ isotopomer flux module; and $\delta^{18} \mathrm{O}$ etc. stands for the transported $\mathrm{CO}_{2}$ and $\delta^{18} \mathrm{O}$ in the atmosphere.

include C4 vegetation (Knorr and Heimann, 2001a). In order to obtain realistic evapotranspiration rates, vegetation temperatures and, therefore, realistic stomatal conductances from the ECHAM energy and water budgets, we recompute the latent and sensible heat fluxes from the canopy. Since plants constantly lose water through their stomatal pores while photosynthesising, water availability is related closely to carbon uptake. A detailed description of the original model can be found in Knorr and Heimann (2001a,b). To interface BETHY to ECHAM, we mainly removed the BETHY internal weather generator and soil model. These variables are taken directly from ECHAM. Deficiencies due to interfacing and not coupling BETHY to ECHAM and other points will be discussed in a subsequent paper.

The ${ }^{18} \mathrm{O}-\mathrm{CO}_{2}$ flux module (OFRAC) follows the overall picture of Farquhar et al. (1993) and Ciais et al. (1997). The main difference between the approaches used in Farquhar et al. (1993), Ciais et al. (1997a,b) and Peylin et al. (1999) and our model is the more credible estimation of the ${ }^{18} \mathrm{O}-\mathrm{CO}_{2}$ fluxes. We use a time step more adapted to physiological processes and compute the ${ }^{18} \mathrm{O}-\mathrm{CO}_{2}$ fluxes interactively in dependence on the synchronous $\mathrm{CO}^{18} \mathrm{O}$ concentration in the atmosphere. Each time step, i.e. each 40 min, BETHY computes assimilation and respiration $\mathrm{CO}_{2}$ fluxes. The ${ }^{18} \mathrm{O}-\mathrm{CO}_{2}$ flux module OFRAC computes for every $\mathrm{CO}_{2}$ flux a corresponding $\mathrm{CO}^{18} \mathrm{O}$ flux, namely to assimilation, respiration, ocean, fossil fuel and biomass burning. The corresponding $\mathrm{CO}^{18} \mathrm{O}$ fluxes are the product of the $\mathrm{CO}_{2}$ fluxes with the isotope ratio of the $\mathrm{CO}_{2}$ dissolved in water and the fractionation occurring at the transition from one compartment to the other (see e.g. Ciais et al., 1997a). $\mathrm{CO}^{18} \mathrm{O}$ is then transported together with $\mathrm{CO}_{2}$ by the AGCM ECHAM as inert tracer. It thus permits one to calculate $\delta^{18} \mathrm{O}$ in atmospheric $\mathrm{CO}_{2}$ each time step, and $\delta^{18} \mathrm{O}-\mathrm{CO}_{2}$ can feedback semi-implicitly on the $\mathrm{CO}^{18} \mathrm{O}$ fluxes. 


\subsection{The experimental data}

In the EUROSIBERIAN CARBONFLUX project are four different aircraft measurement sites for $\mathrm{CO}_{2}$ concentrations together with $\delta^{18} \mathrm{O}-\mathrm{CO}_{2}$ outside the atmospheric boundary layer (ABL): Orléans, France $\left(47^{\circ} 55^{\prime} \mathrm{N}, 1^{\circ} 54^{\prime} \mathrm{E}\right)$, Tver, Russia $\left(56^{\circ} 28^{\prime} \mathrm{N}\right.$, $\left.32^{\circ} 56^{\prime} \mathrm{E}\right)$, Syktyvkar, Russia $\left(61^{\circ} 40^{\prime} \mathrm{N}, 50^{\circ} 45^{\prime} \mathrm{E}\right)$ and Zotino Russia $\left(60^{\circ} 45^{\prime} \mathrm{N}, 89^{\circ} 24^{\prime} \mathrm{E}\right)$ (Levin et al., 2002). In Tver and Zotino there are also eddy-covariance flux towers installed measuring Net Ecosystem Exchange (NEE) (Milyukova et al., 2002; Tchebakova et al., 2002). We include three other sites for NEE from the EUROFLUX network further west to have a meridional coverage: Sarrebourg, France $\left(48^{\circ} 40^{\prime} \mathrm{N}, 7^{\circ} 05^{\prime} \mathrm{E}\right)$ (Granier, 2002), Flakaliden, Sweden $\left(64^{\circ} 14^{\prime} \mathrm{N}\right.$, $19^{\circ} 46^{\prime} \mathrm{E}$ ) (Lindroth, 2002), and Hyytiälä, Finland $\left(64^{\circ} 51^{\prime} \mathrm{N}, 2^{\circ} 17^{\prime} \mathrm{E}\right)$ (Vesala, 2002; Suni, T., personal communication).

We also compare the modelled isotopic signature in precipitation to stations of the Global Network for Isotopes in Precipitation (GNIP) of the International
Atomic Energy Agency (IAEA), Vienna, Austria (IAEA/WMO, 2001). The GNIP database incorporates more than $10^{5}$ measurements of the three isotopes deuterium, tritium, and ${ }^{18} \mathrm{O}-\mathrm{H}_{2} \mathrm{O}$ in precipitation and gives monthly mean values for the measurement, period. The GNIP stations are not identical to the above locations of $\mathrm{CO}_{2}$ measurements, so we selected GNIP stations nearby. These are namely Thononles-Bains, France $\left(46^{\circ} 13^{\prime} \mathrm{N}, 6^{\circ} 16^{\prime} \mathrm{E}\right)$, St. Petersburg, Russia $\left(59^{\circ} 34^{\prime} \mathrm{N}, 30^{\circ} 10^{\prime} \mathrm{E}\right)$, Kirov, Russia $\left(58^{\circ} 23^{\prime} \mathrm{N}\right.$, $\left.49^{\circ} 22^{\prime} \mathrm{E}\right)$, and Enisejsk, Russia $\left(58^{\circ} 16^{\prime} \mathrm{N}, 92^{\circ} 05^{\prime} \mathrm{E}\right)$.

All $\delta^{18} \mathrm{O}-\mathrm{H}_{2} \mathrm{O}$ values of water reported here are relative to the standard Vienna SMOW (VSMOW) (Baertschi, 1976) and $\delta^{18} \mathrm{O}-\mathrm{CO}_{2}$ relative to Vienna Pee Dee belemnite (VPDB-CO ${ }_{2}$ ) (Allison et al., 1995).

\section{Results and discussion}

Figure 2 shows the investigation area together with the locations of the measurement stations. However, we used only the area between $40^{\circ} \mathrm{N}$ and $70^{\circ} \mathrm{N}$ for
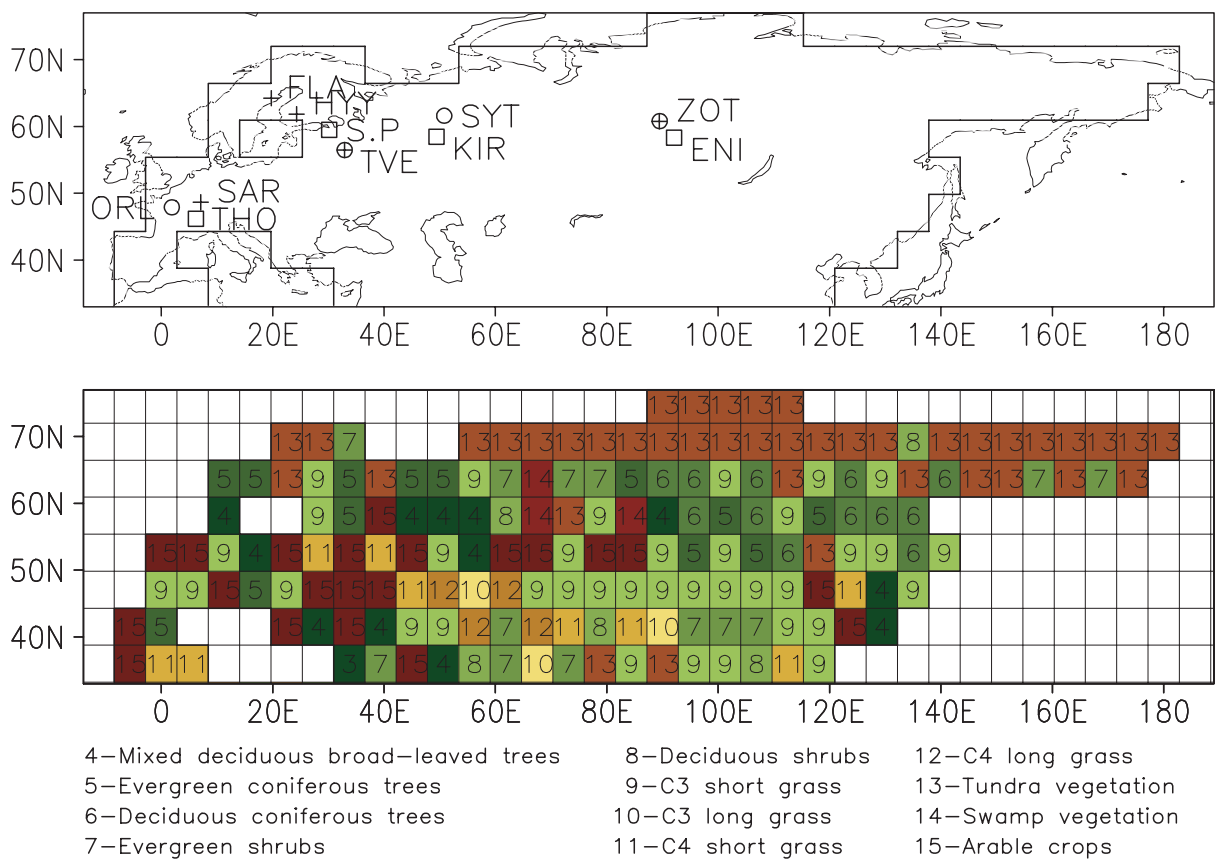

Fig. 2. Two different representations of the investigation area. In the upper frame are indicated the measurement stations of water isotopes (squares), $\mathrm{CO}_{2}$ fluxes (cross) and atmospheric $\mathrm{CO}_{2}$ with isotopes (circles) (ORL, Orléans; THO, Thononles-Bains; SAR, Sarrebourg; FLA, Flakaliden; HYY, Hyytiälä; S.P, St. Petersburg; TVE, Tver; SYT, Syktyvkar; KIR, Kirov; ZOT, Zotino; ENI, Enisejsk). In the lower frame, the boxes are the grids of the model and the colours with numbers stand for each vegetation class used (4-15 of 23 overall in the model). 
the calculation of the longitudinal gradients. But, one should keep in mind that the model is run globally, so it fully accounts for lateral input/output of $\mathrm{H}_{2} \mathrm{O}, \mathrm{CO}_{2}$ and isotopes to/from the Eurasian domain in this study. In the upper plate is also indicated the border of the land masses in the model. Combining the upper with the lower panel gives a clear picture of the used model resolution. In the bottom plate, we show the vegetation distribution which is used in BETHY. There is mostly tundra vegetation in north Siberia and a mixture of evergreen and deciduous conifers over temperate and boreal Eurasia as well as in east Siberia. The southern part is dominated by grasses (C3 and C4) and crops. It is apparent in the vegetation distribution that, apart from the longitudinal gradient in climate due to continentality, a gradient in latitude exists which also plays a role for $\delta^{18} \mathrm{O}-\mathrm{CO}_{2}$.

The $\delta^{18} \mathrm{O}$ signal in $\mathrm{CO}_{2}$ is mainly the convolution of the water isotopic composition with the $\mathrm{CO}_{2}$ fluxes. Hence, both parts of the convolution have to be validated. We compare first the water isotopes with measurements from the GNIP database and next $\mathrm{CO}_{2}$ net fluxes with measurements of eddy-flux towers. We will then compare the seasonal cycle of $\mathrm{CO}_{2}$ and $\delta^{18} \mathrm{O}$ $\mathrm{CO}_{2}$ in the free troposphere, namely at ca. $3000 \mathrm{~m}$ a.s.l.

\subsection{Water isotopes}

On a global scale, a detailed comparison of the water isotope module of ECHAM with global observations of the IAEA observations gave an excellent agreement of the spatial and temporal patterns of the simulated and observed isotope fields (Hoffmann et al., 1998). To illustrate this, we show here some typical results of the monthly $\delta^{18} \mathrm{O}-\mathrm{H}_{2} \mathrm{O}$ in precipitation over Eurasia (Fig. 3). Note that all IAEA stations in Russia are actually closed now, so the presented data include no recent water isotopic composition. Nevertheless, there is no obvious trend in time in the water isotopic composition, so we can use the older data for isotopes in precipitation as an isotope climatology. In Fig. 4 one can clearly see the continental impoverishment in rainfall isotope data at the four selected IAEA stations distributed along the eastward transport trajectory of water vapour over Eurasia. The continental gradient and its origin (the rainout mechanism) is already described in the first review of the IAEA network (Dansgaard, 1964). One can also see that the isotopic composition of the soil water is close to rain water in our model. The difference originates mainly from different infiltration and runoff of winter and summer precipitation

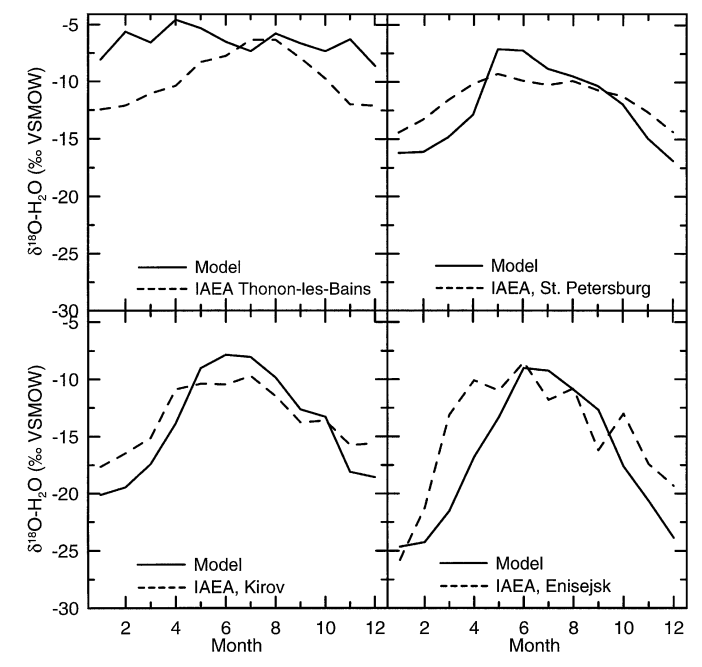

Fig. 3. Comparison of modelled and measured water isotopic composition of precipitation at four selected IAEA stations.

(Hoffmann et al., 1998). Figure 3 illustrates the increasing continentality, which is also linked to an increasing seasonal amplitude, not only in temperature but also in water isotopes (up to $120^{\circ} \mathrm{E}$ approximately). A larger seasonal amplitude of $\delta^{18} \mathrm{O}-\mathrm{H}_{2} \mathrm{O}$ in precipitation is consistently observed (and simulated by ECHAM) in higher latitudes compared to lower latitudes and in the interior of the continents compared to regions under a marine influence. The increasing seasonality of the water isotopes, moving into the continent, mainly lowers the winter values (summer, about -8 to $-10 \%$ both in St. Petersburg and in Enisejsk; winter, $-16 \%$ in St. Petersburg and $-24 \%$ in Enisejsk). As a consequence, the spatial gradient of the water isotopes, strongly expressed in the annual mean and even more in winter, is comparatively weaker during plants' growing season in late spring and summer.

\subsection{Net ecosystem exchange}

Figure 5 shows a comparison of the measured Net Ecosystem Exchange (NEE) on eddy-flux towers with the modelled fluxes of BETHY. Such a comparison should be treated with caution because NEE measurements are representative of a very small area $(<1$ $\mathrm{km}^{2}$ ) compared to our model grid. It is, however, a useful semi-quantitative information of the BETHY model performance. Included is the modelled NEE 


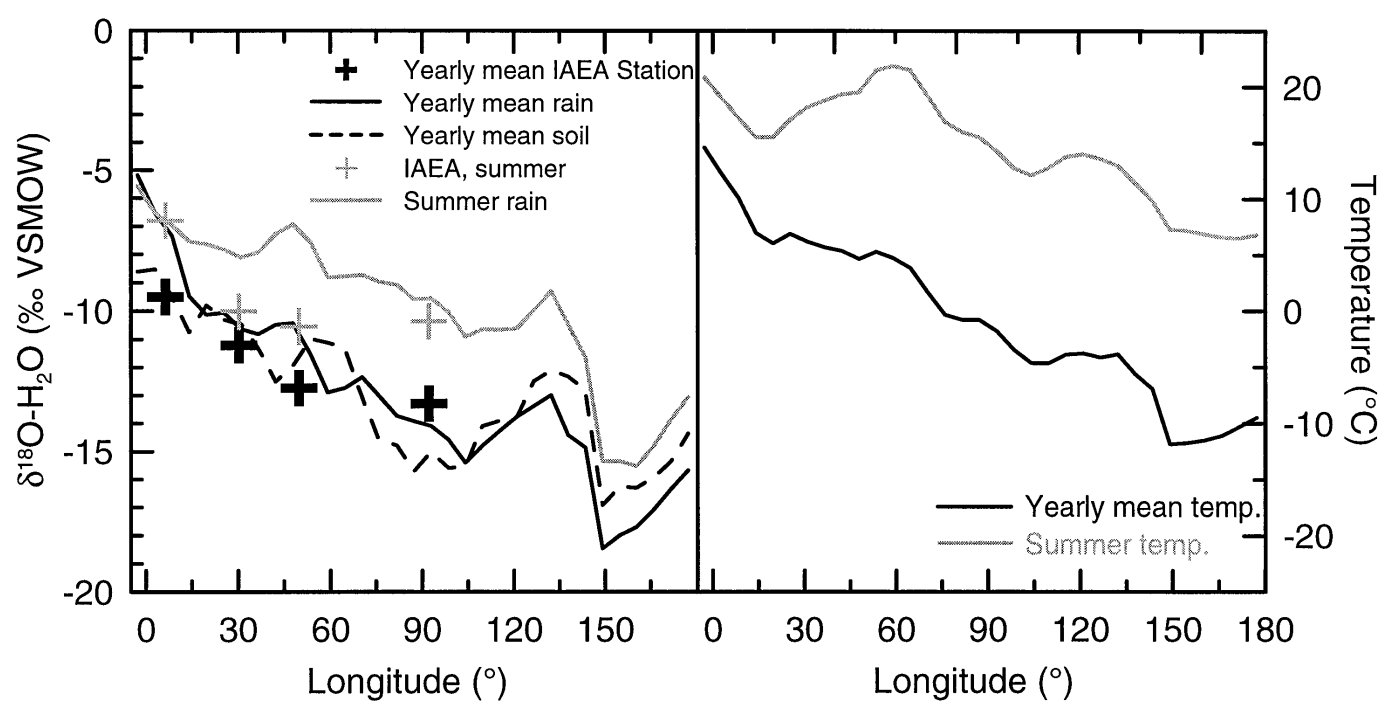

Fig. 4. Longitudinal gradient of water isotopes and temperature over Eurasia of yearly and summer means. The modelled meridional summer and yearly mean rain and soil water are shown in comparison to the four IAEA stations of Fig. 3. The summer composition of soil water is not shown because it is very similar to the yearly mean. The model output is processed like the station data, but the monthly means of the model are already rainfall weighted means.

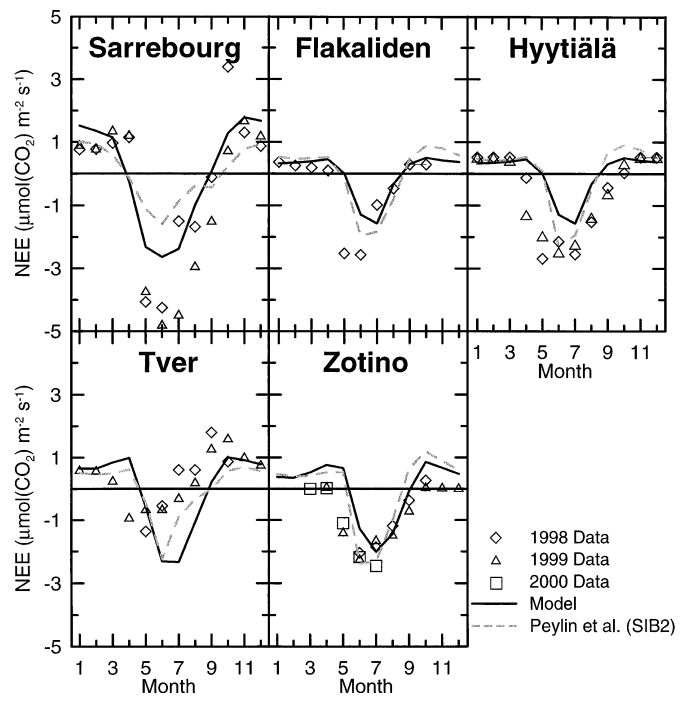

Fig. 5. Net ecosystem exchange (NEE) modelled and measured with eddy-flux towers in Sarrebourg, Flakaliden, Hyytiälä, Tver, and Zotino.

(at monthly time steps) of Peylin et al. (1999), which comes from SIB2 (Sellers et al., 1996a,b), for comparison. BETHY's net fluxes are too small in amplitude but they are realistic for the phase of NEE at almost all flux tower sites. The same is true for the fluxes of SIB2 but with a slightly larger, though more realistic amplitude. BETHY has a larger net flux amplitude only at the most western station, Sarrebourg. Flakaliden is the northernmost station which shows a very sharp decrease of NEE in May probably at the time when the temperature in Flakaliden passes the threshold temperature for assimilation for the dominant species, Picea abies, there. This behaviour is captured by BETHY but is not as pronounced as in the measurements. There is no such abrupt behaviour in Hyytiälä whereas the model still shows a sudden beginning of assimilation. (Hyytiälä falls in the same grid box as Flakaliden in the model.) In Tver, both models are very comparable but BETHY reproduces better the large positive flux to the atmosphere at the end of the growing season. Both models predict too much respiration in Zotino at the end of the year but SIB2 simulates the minimum value in June well. One should recall that NEE is actually the sum of two opposing fluxes, of assimilation and ecosystem respiration, where the maximum of assimilation ranges from $3 \mu \mathrm{mol}\left(\mathrm{CO}_{2}\right) \mathrm{m}^{-2} \mathrm{~s}^{-1}$ in Flakaliden to $7.5 \mu \mathrm{mol}\left(\mathrm{CO}_{2}\right) \mathrm{m}^{-2} \mathrm{~s}^{-1}$ in Tver. The amplitude and the phase of NEE are very sensitive to the phasing of the two fluxes, especially in regions with a contrasted seasonal climate. In contrast, the western part of Eurasia, with a mild climate and hence not as 
pronounced seasonal variations as in the interior, is much more insensitive to the respective phasing of assimilation and respiration.

\subsection{Seasonal cycle of atmospheric measurements}

$\mathrm{CO}_{2}$ and the $\mathrm{CO}^{18} \mathrm{O}$ fluxes emitted into the atmosphere are transported via advection, convection and turbulent diffusion. There is no known fractionation associated with these processes, so $\mathrm{CO}_{2}$ and $\mathrm{CO}^{18} \mathrm{O}$ are transported as passive tracers. We have not closed the carbon cycle budget globally in our model, so we can not strictly compare the absolute values. One flux omitted in the model is deforestation but there is probably only a small seasonality associated with it. So we can still compare the simulated seasonal cycle, both of $\mathrm{CO}_{2}$ and $\delta^{18} \mathrm{O}-\mathrm{CO}_{2}$, with the observations. The upper panel of Fig. 6 shows the mean seasonal cycle of $\mathrm{CO}_{2}$ in $3000 \mathrm{~m}$ a.s.l. as measured (circles) (Levin et al., 2002) and modelled by ECHAM/BETHY (solid line) and Peylin et al. (1999) (dashed line). The atmospheric $\mathrm{CO}_{2}$ concentrations of Peylin et al. are the monthly SIB2 fluxes transported in the TM2 atmospheric transport model (Heimann, 1995). The seasonal cycle of $\mathrm{CO}_{2}$ is well reproduced by both models. The amplitudes of the data and both models are almost the same. Nevertheless at Syktyvkar and Zotino ECHAM/BETHY seems to produce slightly more realistic amplitudes than Peylin et al. and thus seems to

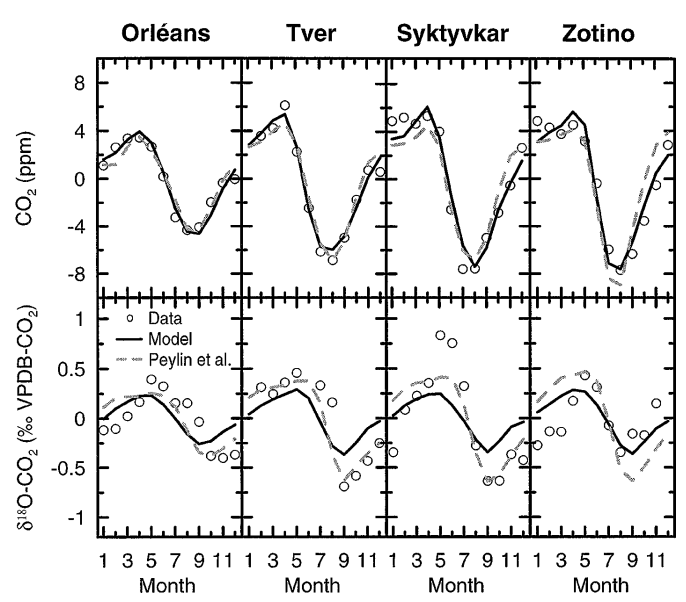

Fig. 6. Measured and modelled mean seasonal cycle of $\mathrm{CO}_{2}$ and $\delta^{18} \mathrm{O}-\mathrm{CO}_{2}$ at Orléans, Tver, Syktyvkar, and Zotino at $3000 \mathrm{~m}$ a.s.1. Note that the data of Tver is not at $3000 \mathrm{~m}$ but a mean seasonal cycle extracted from flights above the atmospheric boundary layer (ABL). capture the seasonal cycle of $\mathrm{CO}_{2}$ better even if its not significant. The lower panel of Fig. 6 shows the mean seasonal cycle in $\delta^{18} \mathrm{O}-\mathrm{CO}_{2}$ with measurements discussed in Levin et al. (2002). The $\mathrm{CO}^{18} \mathrm{O}$ fluxes of Peylin et al. are the synthesis of the SIB2- $\mathrm{CO}_{2}$ fluxes with the GISS water isotopes (Jouzel et al., 1987) on a monthly mean basis and the transport of TM2. Both models follow the phase of the cycle, but Peylin et al. have a higher amplitude. One can clearly see that the amplitude in the $\mathrm{CO}_{2}$ seasonal cycle remains roughly constant when going into the interior of the continent, from Tver to Zotino. Only Orléans is much lower, reflecting its maritime influence. In contrast, the amplitude of $\delta^{18} \mathrm{O}-\mathrm{CO}_{2}$ increases from Orléans to Syktyvkar and then decreases in Zotino again. This behaviour is not well understood (Levin et al., 2002). There are several possible explanations: 1 . There are different transport patterns west and east of the Urals, i.e. west of the Urals is more influenced by the Azores high and the Icelandic low, and east of the Urals is mostly influenced by the Siberian high (winter) and low (summer) (Aizen et al., 2001). Zotino is therefore more influenced by northern latitudes (Levin et al., 2002); 2. The free troposphere is much more influenced by ABL air west of the Ural than east of them, but measurements (Lloyd et al., 2002; Ramonet et al., 2002) and simulations with regional scale models (Chevillard et al., 2002; Kjellström et al., 2002) indicate the contrary; 3. There is a positive gradient of $\mathrm{CO}_{2}$ gross (not necessarily net fluxes, cf. $\mathrm{CO}_{2}$ seasonal cycle) and hence $\delta^{18} \mathrm{O}-\mathrm{CO}_{2}$ fluxes from the Atlantic to the Urals and a negative gradient from the Urals to the Pacific; 4. There is no gradient of the $\mathrm{CO}_{2}$ gross fluxes but there is one in discrimination. Unfortunately, our model does not fully resolve the Ural mountains in its influence on weather regimes because it has a smoothed orography and a rather coarse resolution.

Even if we can not compare the absolute values with the measurements, the longitudinal gradient between Orléans and Zotino should be comparable. In Table 1 are listed the differences in ECHAM/BETHY and in the data of the mean and amplitudes of $\mathrm{CO}_{2}$ and $\delta^{18} \mathrm{O}-$ $\mathrm{CO}_{2}$ between Tver, Syktyvkar, Zotino and Orléans. Table 1 indicates that there is practically no difference in the amplitude of the seasonal cycle of $\mathrm{CO}_{2}$ between the three stations in Russia, but the offset between the means differs considerably Levin et al. (2002) argued that this offset is not significant because the differences do not occur over the whole measurement period and even disappear by the end of 2000 . From $\delta^{13} \mathrm{C}$ measurements in $\mathrm{CO}_{2}$, the authors suggested that there is 
Table 1. Comparison of absolute modelled and measured concentrations relative to Orléans ${ }^{\mathrm{a}}$

\begin{tabular}{|c|c|c|c|c|c|c|}
\hline & \multicolumn{3}{|c|}{ Model } & \multicolumn{3}{|c|}{ Data } \\
\hline & TVE & SYT & ZOT & TVE & SYT & ZOT \\
\hline & - & - & - & - & - & - \\
\hline & ORL & ORL & ORL & ORL & ORL & ORL \\
\hline Mean $\mathrm{CO}_{2}(\mathrm{ppm})$ & 1.1 & 0.6 & 0.3 & $-1.1 \pm 2.4$ & $3.1 \pm 1.9$ & $1.2 \pm 2.1$ \\
\hline \multirow{2}{*}{ Ampl. $\mathrm{CO}_{2}(\mathrm{ppm})$} & 2.8 & 4.9 & 4.6 & $5.2 \pm 2.4$ & $5.1 \pm 1.9$ & $4.7 \pm 2.1$ \\
\hline & $(1.3)$ & (1.6) & $(1.5)$ & $(1.7 \pm 0.7)$ & $(1.7 \pm 0.7)$ & $(1.6 \pm 0.6)$ \\
\hline Mean $\delta^{18} \mathrm{O}-\mathrm{CO}_{2}(\% o)$ & -0.2 & -0.2 & -0.3 & $-0.8 \pm 0.3$ & $-0.8 \pm 0.4$ & $-0.5 \pm 0.4$ \\
\hline \multirow[t]{2}{*}{ Ampl. $\delta^{18} \mathrm{O}-\mathrm{CO}_{2}(\% \circ)$} & 0.2 & 0.1 & 0.2 & $0.4 \pm 0.3$ & $0.7 \pm 0.4$ & $0.0 \pm 0.4$ \\
\hline & $(1.3)$ & $(1.2)$ & (1.3) & $(1.4 \pm 0.9)$ & $(1.8 \pm 1.1)$ & $(1.0 \pm 0.7)$ \\
\hline
\end{tabular}

a ORL, Orléans; TVE, Tver; SYT, Syktyvkar; ZOT, Zotino. Mean is the difference of total averages and Ampl. is the difference in amplitude of the mean seasonal cycles. The values in parentheses are the ratio of the amplitude of the mean seasonal cycle to the amplitude at Orléans.

a big interannual variability in the net fluxes. In contrary, the mean in $\delta^{18} \mathrm{O}-\mathrm{CO}_{2}$ remains almost constant between Tver and Syktyvkar and decreases via Zotino, whereas the amplitude increases from Orléans over Tver to Syktyvkar and decreases approaching Zotino, where it reaches the size of Orléans again. Our model does not capture the behaviour of the data but produces $\delta^{18} \mathrm{O}-\mathrm{CO}_{2}$ fields that are rather uniform in size and amplitude over the whole of Russia. $\delta^{18} \mathrm{O}-\mathrm{CO}_{2}$ does not seem to change significantly over the continent at $3000 \mathrm{~m}$ in the model.

\subsection{Diurnal rectification gradient}

An interesting phenomenon in the carbon cycle, although it hinders an accurate inversion of fluxes, is the covariation between surface fluxes and vertical or horizontal transport, in a generic manner called the rectifier effect. We further investigate here the diurnal rectifier effect (Stephens et al., 1999). During daytime in the growing season, the vertical transport is vigorous and NEE is negative (sink), resulting in a small negative gradient in $\mathrm{CO}_{2}$ concentrations between the surface and the ABL. During night-time, vertical transport is almost suppressed and NEE is positive (source), inducing a large $\mathrm{CO}_{2}$ accumulation near the ground in the shallow nocturnal boundary layer. If one measures only near the ground, the mean concentration in time is shifted to higher values while the mean mid-ABL concentration is shifted to lower $\mathrm{CO}_{2}$ values. Inverse modelling efforts, taking monthly or yearly mean concentrations, have to take into account this spatial gradient induced by the "diurnal rectifier effect" (DRE). Current inverse models mostly take stations on the ocean, where the DRE is not very large if the continental influence can be neglected (Denning et al., 1996). However, stations nearby or inside Eurasia, like the Shemya Islands (Aleutians) or Ulaan Uum (Mongolia), could be strongly influenced by the DRE, the magnitude and extent of which are yet poorly known. There are even inverse models now which invert $\mathrm{CO}_{2}$ and $\delta^{18} \mathrm{O}$ in atmospheric $\mathrm{CO}_{2}$ where the DRE is ignored (Peylin, 1999). The DRE effect is very strong in summer but of minor influence in winter. In addition to the DRE, there are also different transport patterns between summer and winter, vertically and horizontally which also covary with the seasonal pattern of NEE. This effect can lead to another generation of mean spatial concentration gradients (e.g. Denning et al., 1995) and is referred to here as "seasonal rectifier effect" (SRE). Covariations with vertical transports normally induce an enhancement of the measured concentrations near the ground (Stephens et al., 1999), whereas horizontal transport can lead to an abasement (Ciais et al., 2000; Taylor, 1998). The sign of this SRE can be negative or positive depending on the transport patterns and or the regions considered. Our model shows both rectifier effects which are not distinguishable in a normal simulation. To simplify matters, we will also call the overall effect the diurnal rectifier effect because the DRE makes approximately $80 \%$ of the total rectifier effect over land (Denning et al., 1996). Figure 7 illustrates the DRE in ECHAM/BETHY. We show the simulated fields for February, August and the yearly mean $\mathrm{CO}_{2}$ and $\delta^{18} \mathrm{O}-\mathrm{CO}_{2}$ in the first (ca. $30 \mathrm{~m}$ above ground) and third levels (ca. $800 \mathrm{~m}$ above ground) of the model. The third level lies in the middle of the ABL in summertime but in night- and winter-time 
Ground Level

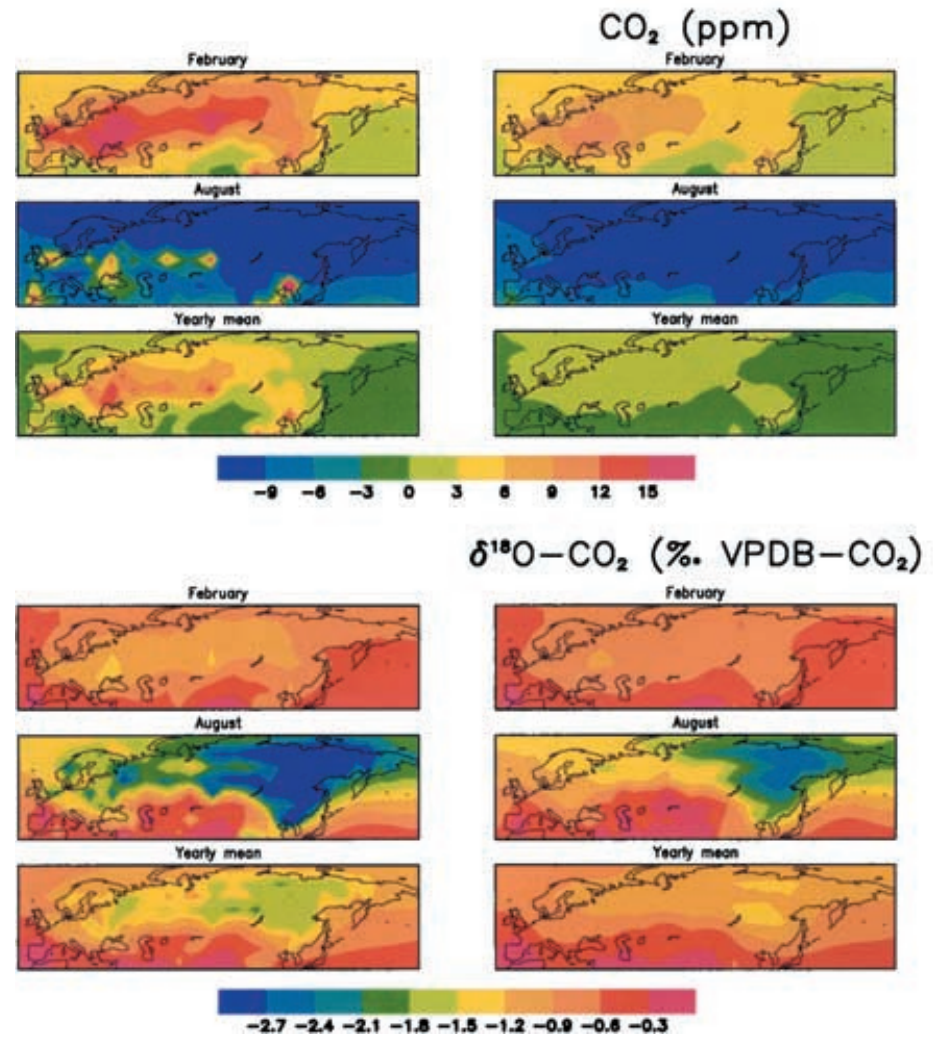

Ground-3 $3^{\text {rd }}$ Level
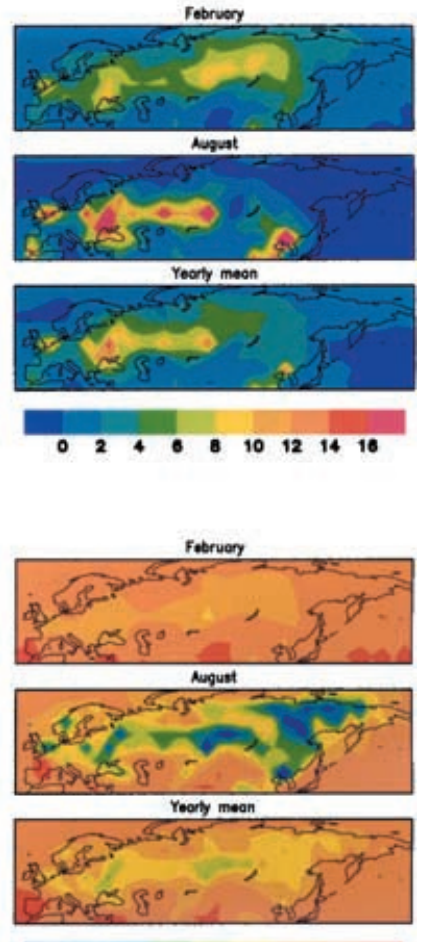

$-1.4-1.2-1-0.8-0.6-0.4-0.20$

Fig. 7. Rectification gradients of $\mathrm{CO}_{2}$ and $\delta^{18} \mathrm{O}-\mathrm{CO}_{2}$ at ground (first column) and third (second column) level of the model, approximately 30 and $800 \mathrm{~m}$ respectively, above ground. The third column is the difference between the first and second column. In the third column, the colour bar differs from those used in columns one and two. We suppressed longitude and latitude labelling to make the plot intelligible. Longitude ranges from 15 to $170^{\circ} \mathrm{W}\left(-15\right.$ to $\left.190^{\circ}\right)$ and latitude ranges from 35 to $75^{\circ} \mathrm{N}$. We substracted the global mean concentration from each grid point as a reference. This gives negative values everywhere in $\delta^{18} \mathrm{O}-\mathrm{CO}_{2}$ over Eurasia because of the simulated strong north-south gradient.

outside it. We also excluded the concentrations of fossil fuel and biomass burning of $\mathrm{CO}_{2}$ and $\delta^{18} \mathrm{O}-\mathrm{CO}_{2}$ in Fig. 7 in order to examine only the rectification gradients induced by covariations of biospheric fluxes and transport. The model shows an accumulation of $\mathrm{CO}_{2}$ at the ground level with respect to $800 \mathrm{~m}$ over the continent on a monthly average basis. This accumulation ranges from $1 \mathrm{ppm}$ over eastern Siberia in winter up to $30 \mathrm{ppm}$ over some regions over western Russia in summer and to $40 \mathrm{ppm}$ over south-east Asia. The wintertime $\mathrm{CO}_{2}$ accumulation is not very pronounced over Eurasia but it reaches a maximum of $10 \mathrm{ppm}$ in south Siberia. Otherwise, it is quite uniform between 2 and $6 \mathrm{ppm}$ in the rest of the investigation area. In summer, there is a vast area between 40 and $60^{\circ} \mathrm{N}$ and 30 and $90^{\circ} \mathrm{E}$ where the monthly mean concentrations at the ground are more than 6-30 ppm higher compared to $800 \mathrm{~m}$. West of it, the DRE again seems to be quite uniform around $3 \mathrm{ppm}$, and east of it the DRE falls even beyond 0 . In summer, the $800 \mathrm{~m}$ level lies most of the time in the CBL during the day and indicates the net effect of daytime NEE with reduced $\mathrm{CO}_{2}$ concentrations. However, $\delta^{18} \mathrm{O}$ in atmospheric $\mathrm{CO}_{2}$ shows a similar pattern in winter as $\mathrm{CO}_{2}$ does. It shows a small accumulation of negative $\delta^{18} \mathrm{O}-\mathrm{CO}_{2}$ (of respired $\mathrm{CO}_{2}$ ) in Europe and western Siberia near the ground, with values around $-0.3 \%$ compared to $800 \mathrm{~m}$. In contrast to western Siberia, we see almost no difference 
between ground- and third-level in $\delta^{18} \mathrm{O}-\mathrm{CO}_{2}$ in winter in eastern Siberia. During summer there is a drawdown in $\delta^{18} \mathrm{O}-\mathrm{CO}_{2}$ between $800 \mathrm{~m}$ and the surface of more than $-0.4 \%$ over the whole domain, reaching values of $-1.5 \%$ around St. Petersburg and around Jakutsk in eastern Siberia. This pattern mirrors the DRE of $\mathrm{CO}_{2}$ in Europe and west Siberia, but it is different over eastern Siberia. This surprising signal over eastern Siberia comes from negative ${ }^{18} \mathrm{O}$ leaf discrimination east of approximately $90^{\circ} \mathrm{E}$ (see below and Fig. 9c). Already at Zotino the DRE signal for $\delta^{18} \mathrm{O}-\mathrm{CO}_{2}$ differs from that of $\mathrm{CO}_{2}$. We have plotted in Fig. 8 vertical profiles up to an altitude of approximately $4500 \mathrm{~m}$ in

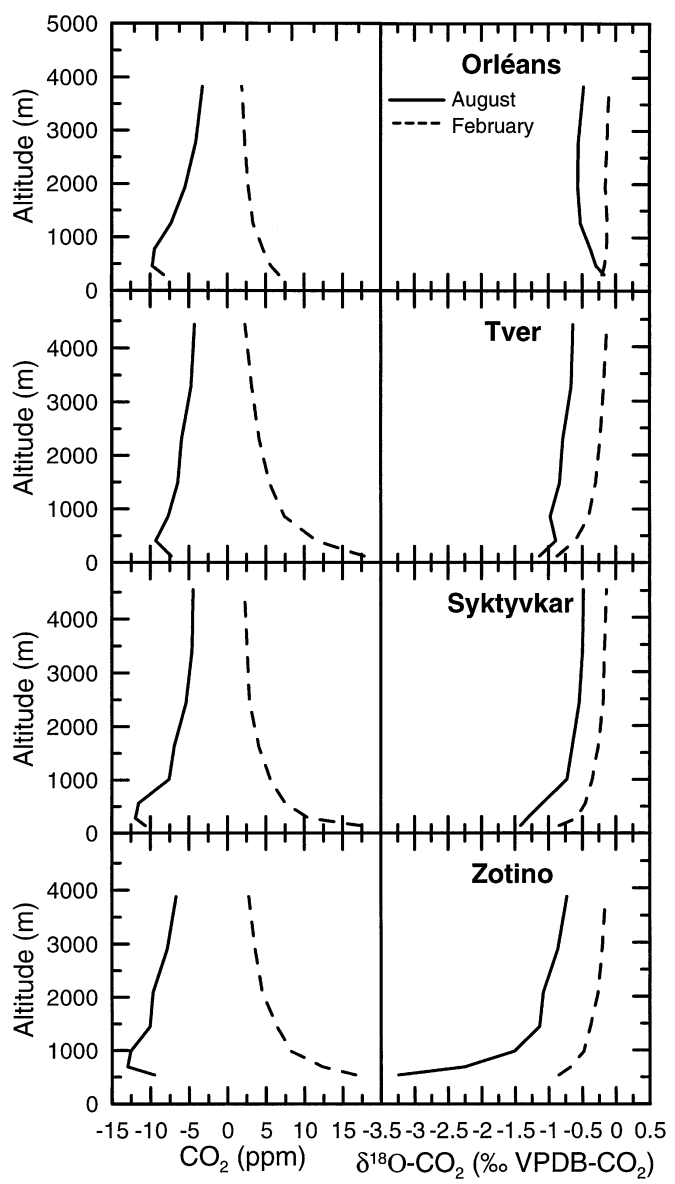

Fig. 8. Simulated monthly mean vertical profiles of $\mathrm{CO}_{2}$ and $\delta^{18} \mathrm{O}_{-} \mathrm{CO}_{2}$ from ground to about $4500 \mathrm{~m}$ at Orléans, Tver, Syktyvkar, and Zotino in August and February, computed from 40 min varying NEE, $\delta^{18} \mathrm{O}-\mathrm{CO}_{2}$ fluxes and atmospheric transport.

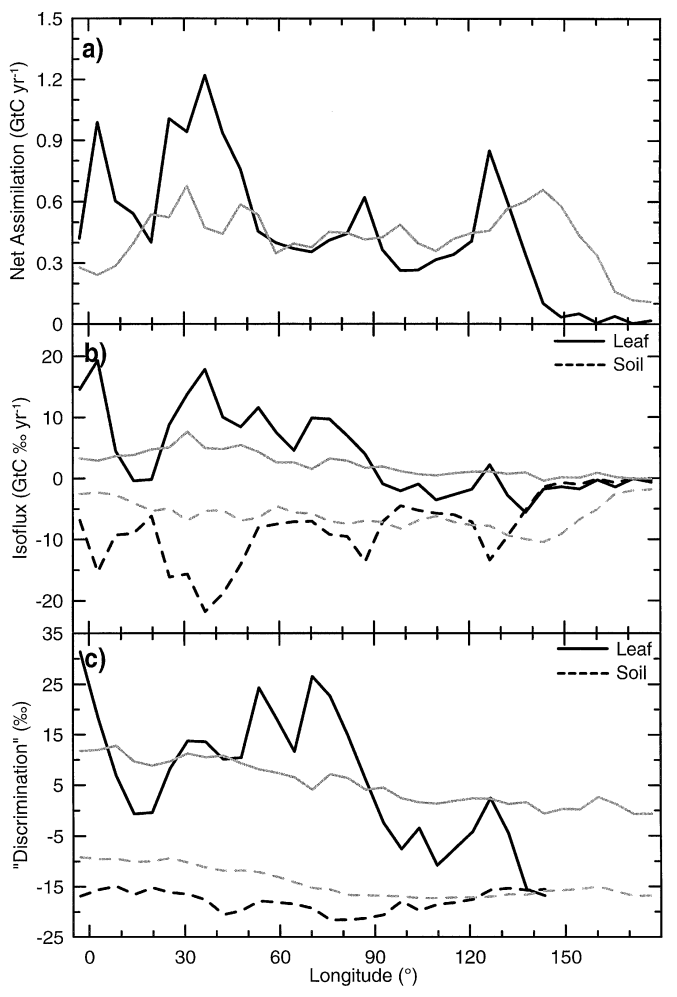

Fig. 9. Yearly mean net carbon assimilation (GPP leaf respiration), isofluxes and their "discriminations" as a function of longitude over Eurasia (top to bottom). Note that NEE is set to zero over each grid cell for a 10-yr run in BETHY and each year in SIB2, so that the ecosystem respiration equals net assimilation. BETHY is in black and Peylin et al. (1999) in grey. (For the definition of isoflux and "discrimination" see the text.)

February and August. We subtracted at each station the value of the tropopause model level (ca. $12 \mathrm{~km}$ ) from the model values. Contrasting Orléans and Zotino in August, one can see that a comparable vertical profile in $\mathrm{CO}_{2}$ (ca. $5 \mathrm{ppm}$ ), reflecting DRE, leads to a very different profile in $\delta^{18} \mathrm{O}-\mathrm{CO}_{2}$. This comes from the fact that leaf discrimination at Zotino is around zero during the growing season in the model, so that the signal of $\delta^{18} \mathrm{O}-\mathrm{CO}_{2}$ is determined mostly by the soil isoflux then (see below and Fig. 9c). One can also notice that the magnitude of the accumulation as well as the difference between ground and $800 \mathrm{~m}$ changes between the stations and thus reflects the specific isoflux sign at each measurement station. Current inverse modelling efforts very rarely include the diurnal cycle, so they include only the seasonal covariations between fluxes 
and transport. Thus, for example, the prediction that assimilation in Siberia must be increased in current biosphere models (Peylin, 1999) could be an artefact. On the other hand, choosing a site where leaf discrimination is zero in summer and measuring vertical profiles would make it possible to quantify the diurnal variation in vertical transport alone, supposing one knows or respectively measures soil "discrimination" (see below). This suggests that $\delta^{18} \mathrm{O}-\mathrm{CO}_{2}$ could be used under these conditions to validate atmospheric transport models to reduce the uncertainties implied by the existence of the DRE.

\subsection{Relating the simulated and observed longitudinal gradients to controlling climate variables}

Writing the global balance equation for $\delta^{18} \mathrm{O}$ in atmospheric $\mathrm{CO}_{2}$ (regarding only the biospheric activity) leads to:

$M_{\mathrm{a}} \frac{\mathrm{d} \delta_{\mathrm{a}}}{\mathrm{d} t}=A \Delta_{A}+F_{R} \Delta_{R}$

with

$\Delta_{A}=-\varepsilon_{1}+\frac{c_{\mathrm{c}}}{c_{\mathrm{a}}-c_{\mathrm{c}}}\left(\delta_{\mathrm{l}}-\delta_{\mathrm{a}}\right)$,

$\Delta_{R}=\delta_{\mathrm{s}}-\delta_{\mathrm{a}}+\varepsilon_{\mathrm{s}}$.

$M_{\mathrm{a}}$ is the number of moles of $\mathrm{CO}_{2}$ in the atmosphere, $\delta_{\mathrm{a}}$ is $\delta^{18} \mathrm{O}$ of atmospheric $\mathrm{CO}_{2}, A$ the net assimilation (assimilation minus leaf respiration), $\Delta_{A}$ the discrimination of assimilation (called leaf discrimination, too), $F_{R}$ the total biospheric respiration minus leaf respiration (heterotrophic plus autotrophic minus leaf respiration), called net ecosystem respiration, $\Delta_{R}$ the difference between soil respired $\delta^{18} \mathrm{O}-\mathrm{CO}_{2}$ and atmospheric $\delta^{18} \mathrm{O}-\mathrm{CO}_{2}$ (we call it soil "discrimination" even if it is not a real discrimination), $\varepsilon_{1}$ the diffusion fractionation of $\mathrm{CO}_{2}$ entering and leaving the stomata, $c_{\mathrm{c}}$ the $\mathrm{CO}_{2}$ concentration at the surface of the chloroplasts, $c_{\mathrm{a}}$ the $\mathrm{CO}_{2}$ concentration of the atmosphere (precisely the canopy), $\delta_{1}$ the $\delta^{18} \mathrm{O}$ of $\mathrm{CO}_{2}$ dissolved and isotopicly equilibrated with leaf water, $\delta_{\mathrm{a}}$ the $\delta^{18} \mathrm{O}$ of atmospheric $\mathrm{CO}_{2}, \delta_{\mathrm{s}}$ the $\delta^{18} \mathrm{O}$ of $\mathrm{CO}_{2}$ dissolved and equilibrated with soil water, and $\varepsilon_{\mathrm{s}}$ the fractionation during diffusion of $\mathrm{CO}_{2}$ out of the soil. The product of $A$ and $\Delta_{A}$ is called the isoflux of assimilation or leaf isoflux and $F_{R}$ times $\Delta_{R}$ is called the isoflux of respiration or soil isoflux. Peylin et al. (1999) calculated separately the assimilation and respiration fluxes and $\Delta$ of assimi- lation and respiration, both on a monthly mean basis. They transported the product of flux times $\Delta$ in TM2.

Having demonstrated that our model reproduces well the water isotopic composition, the $\mathrm{CO}_{2}$ fluxes as well as the atmospheric $\mathrm{CO}_{2}$ concentrations, one can still argue that the amplitude of the seasonal cycle of $\delta^{18} \mathrm{O}-\mathrm{CO}_{2}$ is not well represented in our model (Fig. 6). Conversely, the model matches well the $\delta^{18} \mathrm{O}-\mathrm{CO}_{2}$ values at atmospheric background stations (results not shown here), i.e. stations from e.g. GLOBALVIEW (GLOBALVIEWCO 2,2000 ). However, one can argue that the $\delta^{18} \mathrm{O}-\mathrm{CO}_{2}$ values over the continent are too low because of the amplification of small model shortcomings, e.g. too small convection, the missing "weather barrier" of the Ural or too low isofluxes over Siberia, although the correct phasing of $\delta^{18} \mathrm{O}-\mathrm{CO}_{2}$ in our simulation, together with the rather good fit at atmospheric background stations, indicates that the patterns of assimilation, isofluxes and hence discrimination should be realistic even if the absolute values are not perfectly reproduced. Additionally, none of the existing global models is capable of reproducing $\delta^{18} \mathrm{O}$ in atmospheric $\mathrm{CO}_{2}$ globally in phase and amplitude up to now.

We show in Fig. 9 the meridional gradient of the $\mathrm{CO}_{2}$ fluxes and isofluxes calculated by the ECHAM/ BETHY model. The upper panel (Fig. 9a) shows the annual net assimilation (see above) given in ${\mathrm{GtC} \mathrm{yr}^{-1}}^{-1}$ per longitude band. The black line is the result of our model, again in comparison with Peylin et al. (grey line). Three major points in Fig. 9a are the two maxima in Europe and the difference between BETHY and SIB2 east of $120^{\circ} \mathrm{E}$. The first maxima $\left(5^{\circ} \mathrm{E}\right)$ in assimilation represents western Europe up to South Scandinavia, Central Europe, and the Mediterranean Balkan area, from north to south. Here there is a very temperate climate in ECHAM which is favourable for assimilation. The second large maxima in assimilation around $40^{\circ} \mathrm{E}$ comes from the presence of arable crops around the black sea and in western Russia (Fig. 2). The last maxima of assimilation in BETHY at around $130^{\circ} \mathrm{E}$ corresponds to the great agricultural plains in northern China. East of $20^{\circ} \mathrm{E}$, SIB 2 shows practically no gradient in assimilation, and SIB2 shows larger photosynthesis rates than BETHY in the far north-east Siberian tundra. Both flux models show almost identical total net assimilation for the complete Eurasian domain (north of $40^{\circ} \mathrm{N}$ ), namely $14.5 \mathrm{GtC} \mathrm{yr}^{-1}$, and discarding the peaks in BETHY, both models are roughly similar. The middle panel (Fig. 9b) shows patterns of isofluxes for photosynthesis (straight line) and respiration (dashed line). The lower panel (Fig. 9c) shows $\Delta$, 
the "discrimination" of both photosynthesis (straight line) and respiration (dashed line). $\Delta$ in our model is the division of the isoflux by its $\mathrm{CO}_{2}$ flux and it is therefore a flux-weighted $\Delta$, where the weighting accounts for temporal variability in fluxes each $40 \mathrm{~min}$. Our $\Delta$ thus reflect exactly what is "seen" by the atmosphere. In contrast, Peylin et al. calculated first monthly $\Delta$ and the $\mathrm{CO}_{2}$ fluxes separately, from which they deduced the isofluxes afterwards. Peylin et al. took only relative humidity and the $\mathrm{CO}_{2}$ concentration at the surface of the chloroplast assimilation weighted in the calculation of leaf water isotopic composition, whereas all other variables are taken as monthly averages. They predict a small decrease of the leaf isoflux and a decrease in the soil isoflux from west to east inside Eurasia (ca. $5 \mathrm{GtC}_{\%} \mathrm{yr}^{-1}$ ). ECHAM/BETHY shows noticeably different fields, decreasing in assimilation from about $20 \mathrm{GtC}_{\%} \mathrm{yr}^{-1}$ to small negative values. However, the total isoflux (sum of leaf and soil isoflux) of the biosphere is quite similar for both models over Eurasia. It is remarkable that leaf discrimination (Fig. 9c) in ECHAM/BETHY becomes negative after $90^{\circ} \mathrm{E}$ (the missing values after $150^{\circ} \mathrm{E}$ come from the fact that one divides the isoflux by a very small $\mathrm{CO}_{2}$ flux, which leads to numerical instability and is therefore discarded). Between 50 and $90^{\circ} \mathrm{E}$, the difference between ECHAM/BETHY and Peylin et al. comes certainly from the different assimilation weighting procedures. Both models use the so-called Farquhar formulation (Farquhar et al., 1980) for assimilation. If the assimilation between 50 and $90^{\circ} \mathrm{E}$ is fairly similar in both studies (Fig. 9a), the determining parameters like temperature and humidity should also be quite similar. However, already with temperature, one can see that it will make a big difference in, e.g., the equilibration of $\mathrm{CO}_{2}$ with water $(-0.4 \%$ o per degree increase) if one considers explicitly a diurnal cycle. We try to understand what determines the continentality gradient in Fig. 9c. The leaf discrimination is determined by the isotopic composition of $\mathrm{CO}_{2}$ equilibrated with leaf water at the evaporating site, $\delta_{1}$, the atmospheric $\delta^{18} \mathrm{O}-\mathrm{CO}_{2}$ value, and the factor $c_{\mathrm{c}} /\left(c_{\mathrm{a}}-c_{\mathrm{c}}\right)$ which is the amplification of leaf fractionation due to back-diffusion [Eq. 2]. The leaf water at the evaporating site is calculated from the formulation of Craig and Gordon:

$\delta_{1}^{\mathrm{w}}=\varepsilon_{1}^{\mathrm{w}}+\delta_{\mathrm{s}}^{\mathrm{w}}-\varepsilon_{\mathrm{k}}+h\left(\delta_{\mathrm{vap}}-\delta_{\mathrm{s}}^{\mathrm{w}}+\varepsilon_{\mathrm{k}}\right)$.

$\varepsilon_{1}^{\mathrm{W}}$ is the fractionation of the liquid-vapour phase transition [according to Majoube, (1971)], $\delta_{\mathrm{s}}^{\mathrm{w}}$ the source water isotopic composition, $\varepsilon_{\mathrm{k}}$ the kinetic fractionation factor (taken constant), $h$ the relative humidity, and $\delta_{\text {vap }}$ the isotopic composition of water vapour. $\mathrm{CO}_{2}$ equilibrated with this leaf water is then:

$\delta_{1}=\varepsilon_{1}^{\mathrm{w}}+\varepsilon_{\mathrm{eq}}$,

where $\varepsilon_{\text {eq }}$ is the equilibrium fractionation calculated after Brenninkmeier et al. (1983).

In Fig. 10 are plotted the variables which determine the "discriminations" and hence the isofluxes. We plotted both the assimilation-weighted (black lines) and the plain variables (grey lines). (Assimilationweighted variables are multiplied with the assimilation flux at each time step, and the yearly sum of these products is then divided by the yearly sum of assimilation. They therefore give more realistic mean values.) One can divide northern Eurasia into two parts: the western part from the Atlantic to the Ural (Europe) and the eastern part from the Ural to the Pacific (Siberia), say from 0 to $60^{\circ} \mathrm{E}$ and from 60 to $180^{\circ} \mathrm{E}$. We observe in Fig. 10 an increase in leaf temperature (Fig. 10a) and thus in $\delta^{18} \mathrm{O}-\mathrm{CO}_{2}$ (Fig. 10e) equilibrated with leaf water (at the evaporating site) in

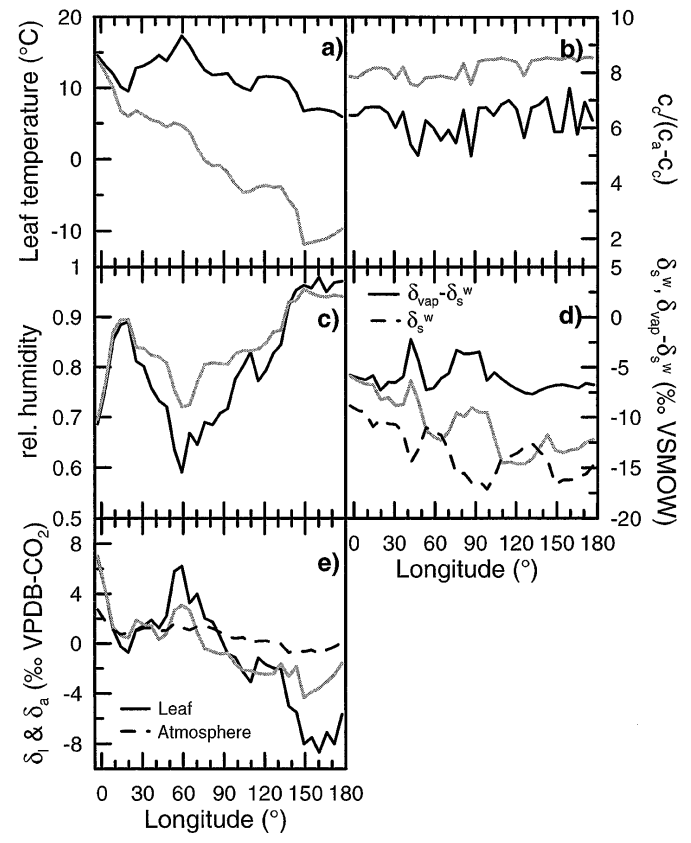

Fig. 10. Variables which determine the $\delta^{18} \mathrm{O}-\mathrm{CO}_{2}$ discrimination of assimilation. Black lines are assimilation-weighted values, and grey lines are not assimilation-weighted (see text for the difference between assimilation-weighted or not). 
Europe and a decrease in Siberia. The converse picture is true for relative humidity (Fig. 10c) in the canopy. $\delta^{18} \mathrm{O}-\mathrm{H}_{2} \mathrm{O}$ of groundwater (Fig. 10d) decreases by about $-5 \%$ over the whole continent, whereas $\delta^{18} \mathrm{O}$ $\mathrm{H}_{2} \mathrm{O}$ vapour minus ground water stays constant despite some fluctuations (Fig. 10d). This leads to an overall decrease in leaf $\delta^{18} \mathrm{O}-\mathrm{H}_{2} \mathrm{O}$ across Siberia of around $-20 \%$ o between the Ural and the Pacific. In this signal, $-5 \%$ o comes from the decrease in source isotope composition and almost $-15 \%$ comes from the increase in relative humidity. The temperaturecontrolled equilibration of $\mathrm{CO}_{2}$ with water isotopes opposes this big drop. However, the assimilationweighted leaf temperature (Fig. 10a) decreases by only $10^{\circ} \mathrm{C}$ across Siberia, so it lowers the gradient in $\delta_{1}$ only by about $-2 \%$ o (Fig. 10e). Since the model shows no east-west gradient in atmospheric $\delta^{18} \mathrm{O}-\mathrm{CO}_{2}$ (Fig. 10e), the decrease of $\delta_{1}$ over Siberia is amplified by $c_{\mathrm{c}} /\left(c_{\mathrm{a}}-c_{\mathrm{c}}\right)$ (Fig. 10b) and leads to the strong eastwest gradient of leaf discrimination of about $-40 \%$ o (Fig. 9c).

\section{Conclusions}

We constructed a model of biospheric $\mathrm{CO}_{2}$ exchange interfaced to an AGCM which also fits with a calculation of the isotopic composition of water. We implemented a new module to calculate, in a fully consistent manner with climate, the cycling of ${ }^{18} \mathrm{O}-\mathrm{H}_{2} \mathrm{O}$ in the surface water pools (soil, leaves) and the pertaining $\delta^{18} \mathrm{O}-\mathrm{CO}_{2}$ fluxes exchanged with the overlaying atmosphere. We studied the space and time distribution of water oxygen isotopes, $\mathrm{CO}_{2}$ biospheric fluxes, atmospheric $\mathrm{CO}_{2}$ and $\delta^{18} \mathrm{O}$ in atmospheric $\mathrm{CO}_{2}, \delta^{18} \mathrm{O}-\mathrm{CO}_{2}$ fluxes, the isotopic discrimination of assimilation, and the isotopic "discrimination" of respiration with respect to $\mathrm{CO}_{2}$ across northern Eurasia. It is shown that the water isotopic composition is simulated well and shows a realistic meridional negative gradient going from west to east. This gradient is much smaller for summer than for winter, so the relevant gradient in water isotopic composition is only about $-5 \%$. The NEE flux that we simulate appears too small in amplitude at the selected flux tower sites, but the comparison can be only semi-quantitative. The seasonal cycle at $3000 \mathrm{~m}$ a.s.l. of $\delta^{18} \mathrm{O}$ in atmospheric $\mathrm{CO}_{2}$ offers an unique integrated measure of the performances of our different modules (NEE, transport, $\delta^{18} \mathrm{O}-\mathrm{CO}_{2}$, etc., and their interactions). The atmospheric seasonal cycle is modelled very well for $\mathrm{CO}_{2}$, but the amplitude of $\delta^{18} \mathrm{O}-\mathrm{CO}_{2}$ is underestimated, although the model reproduces the right phase.

We found that the diurnal rectifier effect, implied by covariations of biotic fluxes with vertical transport in the ABL, is very pronounced over Eurasia and different between $\mathrm{CO}_{2}$ and $\delta^{18} \mathrm{O}-\mathrm{CO}_{2}$. This comes mostly from the fact that leaf discriminations become zero or negative even in the yearly mean east of $90^{\circ} \mathrm{E}$, due to the continentality.

Together with the isofluxes of $\delta^{18} \mathrm{O}-\mathrm{CO}_{2}$, we demonstrated that there is a large gradient in leaf discrimination from west to east over Eurasia, and leaf discrimination can even become negative in the most continental area of eastern Siberia. We interpret this signal on one hand from the water isotope gradient but mostly from the gradient in relative humidity that lowers the evaporating leaf water $\delta^{18} \mathrm{O}-\mathrm{H}_{2} \mathrm{O}$ and, therefore, the leaf discrimination.

\section{Acknowledgements}

We are very grateful for fruitful discussions with Philippe Peylin and Uwe Langendörfer. We also thank Tanja Suni and Timo Vesala for the revision of the Hyytiälä flux data and Tuula Alto for the preparation of other EUROFLUX data. Computing facilities were provided by the German Climate Computing Center (DKRZ) in Hamburg.

\section{REFERENCES}

Aizen, E. M., Aizen, V. B., Melack, J. M., Nakamura, T. and Ohta, T. 2001. Precipitation and atmospheric circulation patterns at mid-latitudes of Asia. Int. J. Climatol. 21, 535556.

Allison, C. E. Francey, R., J. and Meijer, H. A. 1995. Recommendations for the reporting of stable isotope measurements of carbon and oxygen in $\mathrm{CO}_{2}$ gas. In: Refer- ences and intercomparison materials for stable isotopes of light elements, proceedings of a consultant Meeting held in Vienna, 1-3 December 1993, IAEA-TECDOC-825. Int. Atomic Energy Agency, Vienna, 155-162.

Arpe, K., Bengtsson, L., Dümenil, L. and Roeckner, E. 1994. The hydrological cycle in the ECHAM3 simulations of the atmospheric circulation. In: Global precipitation

Tellus 54B (2002), 5 
and climate change (eds. M. Desbois and F. Desalmand). Springer-Verlag, New York, 361-377.

Baertschi, P. 1976. Absolute ${ }^{18} \mathrm{O}$ content of Standard Mean Ocean Water. Earth Planet. Sci. Lett. 31, 341-344.

Bousquet, P., Peylin, P., Ciais, P., Friedlingstein, P. and Tans, P. P. 2000. Regional Changes in Carbon dioxide fluxes of land and oceans since 1980. Science 290, 1342-1346.

Brenninkmeijer, C. A. M., Kraft, P. and Mook, W. G. 1983. Oxygen isotope fractionation between $\mathrm{CO}_{2}$ and $\mathrm{H}_{2} \mathrm{O}$. Isotope Geosci. 1, 181-190.

Chevillard, A., Karstens, U., Ciais, P., Lafont, S. and Heimann, M. 2002. Simulation of atmospheric $\mathrm{CO}_{2}$ over Europe and Siberia using the regional scale model REMO. Tellus 54B, this issue.

Ciais, P., Tans, P. P., Trolier, M., White, J. W. C. and Francey, R. J. 1995. A large northern hemisphere terrestrial $\mathrm{CO}_{2}$ sink indicated by the ${ }^{13} \mathrm{C} /{ }^{12} \mathrm{C}$ ratio of atmospheric $\mathrm{CO}_{2}$. Science 269, 1098-1102.

Ciais, P., Denning, S., Tans, P. P., Berry, J., Randall, D. A., Collatz, G. J., Sellers, P. J., White, J. W. C., Trolier, M., Mejier, H. A. J., Francey, R. J., Monfray, P. and Heimann, M. 1997a. A three-dimensional synthesis of $\delta^{18} \mathrm{O}$ in atmospheric $\mathrm{CO}_{2}$ : 1. Surface fluxes. J. Geophys. Res. 102, D5, 5857-5872.

Ciais, P., Tans, P. P., Denning, S., Francey, R. J., Trolier, M., Mejier, H. A. J., White, J. W. C., Berry, J., Randall, D. A., Collatz, G. J., Sellers, P. J., Monfray, P. and Heimann, M. 1997b. A three-dimensional synthesis of $\delta^{18} \mathrm{O}$ in atmospheric $\mathrm{CO}_{2}: 1$. Simulations with the TM2 transport model. J. Geophys. Res. 102, D5, 5873-5883.

Ciais, P., Peylin, P. and Bousquet, P. 2000. Regional biospheric carbon fluxes as inferred from atmospheric $\mathrm{CO}_{2}$ measurements. Ecol. Appl. 10, 1574-1589.

Dansgaard, W. 1964. Stable isotopes in precipitation. Tellus 16, 436-468.

Denning, A. S., Fung, I. Y. and Randall, D. A. 1995. Latitudinal gradient of atmospheric $\mathrm{CO}_{2}$ due to seasonal exchange with land biota. Nature 376, 240-243.

Denning, A. S., Randall, D. A., Collatz, G. J. and Sellers, P. J. 1996. Simulations of terrestrial carbon metabolism and atmospheric $\mathrm{CO}_{2}$ in a general circulation model, Part 2: Simulated $\mathrm{CO}_{2}$ concentrations. Tellus 48B, 543-567.

Fan, S., Gloor, M., Mahlman, J., Pacala, J., Sarmiento, J., Takahashi, T. and Tans, P. P. 1998. Atmospheric and oceanic $\mathrm{CO}_{2}$ data and models imply a large terrestrial carbon sink in North America. Science 282, 442-446.

Farquhar, G. D., von Caemmener, S. and Berry, J. A. 1980. A Biochemical model of photosynthesis $\mathrm{CO}_{2}$ fixation in leaves of C3 species. Planta 149, 78-90.

Farquhar, G. D., Lloyd, J., Taylor, J. A., Flanagan, L. B., Syvertson, J. P., Hubick, K. T., Wong, S. C. and Ehleringer, J. R. 1993. Vegetation effects on the isotope composition of oxygen in atmospheric $\mathrm{CO}_{2}$. Nature 363, 439-443.

GLOBALVIEW- $\mathrm{CO}_{2}$. 2000. Cooperative Atmospheric Data Integration Project-Carbon Dioxide. CD-ROM, NOAA/CMDL, Boulder, Colorado. Also available on Internet via anonymous FTP to ftp.cmdl.noaa.gov, Path: $\mathrm{ccg} / \mathrm{CO}_{2} /$ GLOBALVIEW.
Granier, A. 2002. Sarrebourg, France, The Euroflux data set 2000. In: Carbon, water and energy exchanges of european forests (ed. R. Valentini). Springer Verlag, Heidelberg (in press).

Heimann, M. 1995. The global atmospheric tracer model TM2. Deutsches Klimarechenzentrum, Hamburg, Germany.

Hoffmann, G., Werner, M. and Heimann, M. 1998. Water isotopes module of the ECHAM atmospheric general circulation model: a study on timescales from days to several years. J. Geophys. Res. 103, D14, 16871-16896.

IAEA/WMO, A.A.A. 2001. Global Network for Isotopes in Precipitation. The GNIP Database. Accessible at: http://isohis.iaea.org.

Jouzel, J., Russell, G. L., Suozzo, R. J., Koster, R. D., White, J. W. C. and Broecker, W. S. 1987. Simulations of the HDO and $\mathrm{H}_{2}{ }^{18} \mathrm{O}$ atmospheric cycles using the NASA GISS general circulation model: the seasonal cycle for present-day conditions. J. Geophys. Res., 92, 14739-14760.

Kjellström, E., Holmén, K., Eneroth, K. and Engardt, M. 2002. Summertime Siberian $\mathrm{CO}_{2}$ simulations with the regional transport model MATCH: a feasibility study of carbon uptake calculations from EUROSIB data. Tellus, $\mathbf{5 4 B}$, this issue.

Knorr, W. and Heimann, M. 2001a. Uncertainties in global terrestrial biosphere modeling, 1. A comprehensive sensitivity analysis with a new photosynthesis and energy balance scheme. Global Biogeochem. Cycles 15, 207225.

Knorr, W. and Heimann, M. 2001b. Uncertainties in global terrestrial biosphere modeling, 2. Global constraints for a process-based vegetation model. Global Biogeochem. Cycles 15, 227-246.

Levin, I., Ciais, P., Gloor, M., Langenfelds, R., Ramonet, M., Sidorov, K., Schmidt, M., Schulze, E.-D., Shibistova, O., Tschebakova, N., Vygodskaya, N. N. and Lloyd, J. 2002. Three years of trace gas observations over the EUROSiberian domain derived from aircraft sampling-a concerted action. Tellus 54B, this issue.

Lindroth, A. 2002. Flakaliden, Sweden, The Euroflux data set 2000. In: Carbon, water and energy exchanges of european forests (ed. R. Valentini). Springer Verlag, Heidelberg (in press).

Lloyd, J., Langenfelds, R., Francey, R. J., Gloor, M., Tchebokova, N. H. and coauthors 2002. A trace gas climatology above Zotino, Central Siberia. Tellus 54B, this issue.

Majoube, M. 1971. Fractionnement en oxygene-18 et en deuterium entre l'eau et sa vapeur. J. Chim. Phys. 58, 14231436.

Mills, G. A. and Urey, H. C. 1940. The kinetics of isotopic exchange between carbon dioxide, bicarbonate ion, carbonate ion and water. J. Am. Chem. Soc. 62, 10191026.

Milyukova, I. M., Kolle, O. E., Varlagin, A. B., Vygodskaya, N. N., Schulze, E.-D. and Lloyd, J. 2002. Carbon balance of a southern taiga spruce stand in European Russia. Tellus $\mathbf{5 4 B}$, this issue. 
Modellbetreuungsgruppe. 1994. The ECHAM3 atmospheric general circulation model. Deutsches Klimarechenzentrum, Hamburg, Germany.

Peylin, P. 1999. The composition of ${ }^{18} \mathrm{O}$ in atmospheric $\mathrm{CO}_{2}$ : new tracer to estimate global photosynthesis. Dissertation. L'Université Paris VI, Paris, France (in French).

Peylin, P., Ciais, P., Denning, A. S., Tans, P. P., Berry, J. A. and White, J. W. C. 1999. A three-dimensional study of $\delta^{18} \mathrm{O}$ in atmospheric $\mathrm{CO}_{2}$ : contribution of different land ecosystems. Tellus 51B, 642-667.

Prentice, I. C., Farquhar, G. D., Fasham, M. J. R., Goulden, M. L., Heimann, M., Jaramillo, V. J., Kheshgi, H. S., Le Quéré, C., Scholes, R. J. and Wallace, D. W. R. 2001. Chapter 3: The carbon cycle and atmospheric $\mathrm{CO}_{2}$, In: Third Assessment Report of Climate Change (eds. J. T. Houghton and D. Yihui). Cambridge University Press, New York. Report of the International Panel on Climate Change.

Ramonet, M., Ciais, P., Nepomniachii, I., Sidorov, K., Lloyd, J., Neubert, R., Picard, D., Kazan, V., Biraud, S., Kolle, O. and Schulze, E.-D. 2002. Three years of aircraft $\mathrm{CO}_{2}$ and isotope measurements over Fyodorovskoye in European Russia. Tellus 54B, this issue.

Rasch, P. J. and Williamson, D. L. 1990. Computational aspects of moisture transport in global models of the atmosphere. Q. J. R. Meteorol. Soc. 116, 1071-1090.

Rayner, P. J., Enting, I. G., Francey, R. J. and Langenfelds, R. 1999. Reconstructing the recent carbon cycle from atmospheric $\mathrm{CO}_{2}, \delta^{13} \mathrm{C}$ and $\mathrm{O} 2 / \mathrm{N} 2$ observations. Tellus 51B, 213-232.

Roeckner, E., Arpe, K., Bengtsson, L., Brinkop, S., Dümenil, L., Esch, M., Kirk, E., Ponater, M., Rockel, B., Sausen, R., Schlese, U., Schubert, S. and Windelband, M. 1992. Simulation of the present-day climate with the ECHAM model: impact of model physics and resolution. MPIReport 93. Max-Planck Inst. für Meteorol., Hamburg, Germany.

Schimel, D., Alves, D., Enting, I. G., Heimann, M., Joos, F., Raynaud, D., Wigley, T. M. L., Prather, M., Derwent, R., Ehhalt, D., Fraser, P., Sabhueza, E., Zhou, X., Jonas, P., Charlson, R., Rohde, H., Sadasivan, S., Shine, K. P., Fouquart, Y., Ramaswamy, V., Solomon, S., Srinivasan,
J., Albritton, D., Derwnet, R., Isaksen, I., Lal, M. and Wuebbles, D. 1996. Chapter 2: Radiative Forcing of Climate Change. In: Climate change 1995, the science of climate change (eds. J.T. Houghton, L.G. Meira Filho, B.A. Callender, N. Harris, A. Kattenberg, and K. Maskell), Cambridge University Press, Cambridge. Report of the International Panel on Climate Change.

Sellers, P. J., Randall, D. A., Collatz, G. J., Berry, J. A., Field, C. B., Dazlich, D. A., Zhang, C. and Collelo, G. D. 1996a. A revised land surface parameterization (SiB2) for atmospheric GCM, Part I. Model formulation. J. Climate 9, 676-705.

Sellers, P. J., Los, S. O., Tucker, C. J., Justice, C. O., Dazlich, D. A., Collatz, G. J. and Randall, D. A. 1996b. A revised land surface parameterization $(\mathrm{SiB} 2)$ for atmospheric GCM, Part II. The generation of global fields of terrestrial biospherical parameters from satellite data. $J$. Climate 9, 706-737.

Stephens, B. B., Wofsy, S. C., Keeling, R. F., Tans, P. P. and Potosnak, M. J. 1999. The $\mathrm{CO}_{2}$ budget and rectification airborne study: Strategies for measuring rectifiers and regional fluxes. In: Inverse methods in global biogeochemical cycles (eds. P. Kasibhatla et al.). Geophysical Monograph Series 114. American Geophysical Union, Washington, DC, 311-324.

Taylor, J. A. 1998. Atmospheric mixing and the $\mathrm{CO}_{2}$ seasonal cycle. Geophys. Res. Lett. 25, 4173-4176.

Tchebakova, N. M., Kolle, O., Zolotoukhine, D., Arneth, A., Styles, J., Vygodskaya, N. N., Schulze, E.-D. and Lloyd, J. 2002. Inter-annual and seasonal variations of energy and water vapour fluxes above a Pinus sylvestris forest in the Siberian middle taiga. Tellus $\mathbf{5 4 B}$, this issue.

Vesala, T. 2002. Hyytiälä, Finland, The Euroflux data set 2000. In: Carbon, water and energy exchanges of europeanforests (ed. R. Valentini). Springer Verlag, Heidelberg (in press).

Werner, M. 2000. Spatial and temporal variability of water isotopes in polar precipitation. Dissertation, Universität Hamburg, Germany (in German).

Wilson, M. F. and Henderson-Sellers, A. 1985. A global archive of land cover and soils data for use in general circulation models. J. Climate 5, 119-143. 